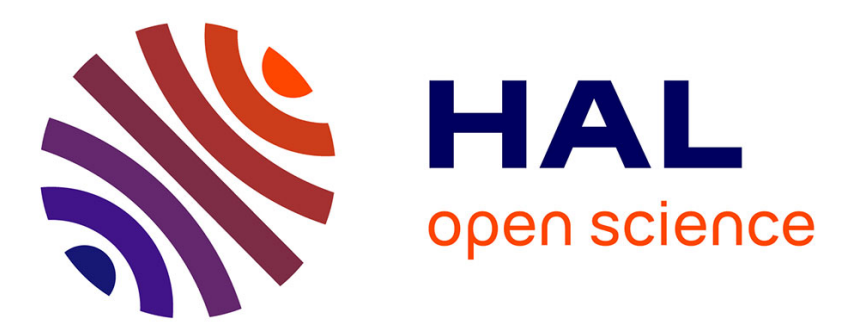

\title{
cAMP-dependent protein kinase inhibits the mitogenic action of vascular endothelial growth factor and fibroblast growth factor in capillary endothelial cells by blocking Raf activation.
}

Gisela d'Angelo, H Lee, R Weiner

\section{To cite this version:}

Gisela d'Angelo, H Lee, R Weiner. cAMP-dependent protein kinase inhibits the mitogenic action of vascular endothelial growth factor and fibroblast growth factor in capillary endothelial cells by blocking Raf activation.. Journal of Cellular Biochemistry, 1997, 67 (3), pp.353-66. hal-03034056

\author{
HAL Id: hal-03034056 \\ https://hal.science/hal-03034056
}

Submitted on 9 Dec 2021

HAL is a multi-disciplinary open access archive for the deposit and dissemination of scientific research documents, whether they are published or not. The documents may come from teaching and research institutions in France or abroad, or from public or private research centers.
L'archive ouverte pluridisciplinaire HAL, est destinée au dépôt et à la diffusion de documents scientifiques de niveau recherche, publiés ou non, émanant des établissements d'enseignement et de recherche français ou étrangers, des laboratoires publics ou privés. 


\title{
CAM P-Dependent Protein Kinase Inhibits the Mitogenic Action of Vascular Endothelial G rowth Factor and Fibroblast Growth Factor in Capillary Endothelial Cells by Blocking Raf Activation
}

\author{
Gisela D'Angelo,* H sinyu Lee, and Richard I. Weiner \\ Department of O bstetrics, Gynecology and Reproductive Sciences, University of California School \\ of Medicine, San Francisco, California 94143
}

\begin{abstract}
Proliferation of endothelial cells is regulated by angiogenic and antiangiogenic factors whose actions are mediated by complex interactions of multiple signaling pathways. Both vascular endothelial growth factor (VEG F) and basic fibroblast growth factor (bFGF) stimulate cell proliferation and activate the mitogen-activated protein kinase (MAPK) cascade in bovine brain capillary endothelial (BBE) cells. We have extended these findings to show that both mitogens activate MAPK via stimulation of Raf-1. Activation of Raf/M APK is inhibited by increasing intracellular cAM P levels pharmacologically or via stimulation of endogenously expressed $\beta$-adrenergic receptors. Both VEGF- and bFGF-induced Raf-1 activity are blocked in the presence of forskolin or 8-bromo-cAMP by $80 \%$. The actions of increased CAM P appear to be mediated by CAM P-dependent protein kinase (PKA), since treatment with $\mathrm{H}-89$, a the specific inhibitor of PKA, reversed the inhibitory effect of elevated CAM P levels on mitogen-induced cell proliferation and Raf/M APK activation. Moreover, elevations in CAMP/PKA activity inhibit mitogen-induced cell proliferation. These findings demonstrate, in cultured endothelial cells, that the CAMP/PKA signaling pathway is potentially an important physiological inhibitor of mitogen activation of the MAPK cascade and cell proliferation. J. Cell. Biochem. 67:353-366, 1997. (1) 1997 Wiley-Liss, Inc.
\end{abstract}

Key words: PKA; Raf-1; MAPK; endothelial cells

Angiogenesis, the sprouting of new capillaries from the preexistent blood vessels, is of central importance in many biological processes, including embryonic vascular development and differentiation, wound healing, and organ regeneration [Klagsbrun and D'Amore, 1991; Folkman and Shing, 1992]. In addition, angiogenesis also plays a major role in pathological conditions such as diabetic rethinopathy, rheumatoid arthritis, psoriasis, cardiovascular diseases, and tumor growth and metastasis [Lei bovich and Polverini, 1984; Folkman, 1985]. During angiogenesis, endothelial cells undergo migration with concomitant proliferation and tube formation and participatein proteolytic degradation of the basement membrane and extracellular matrix. This cascade

*Correspondence to: Gisela D'Angelo, Laboratoire de Remodelage Cardiovasculaire, INSERM U460, Faculté de Médecine Xavier Bichat, 75018 Paris, France.

Received 11 February 1997; Accepted 7J uly 1997 was shown to beregulated by a variety of growth factors, including members of the fibroblast growth factors family (FGF)-for example, basic FGF [Esch et al., 1985; Thomas, 1987] and the vascular endothelial growth factor (VEGF) [Connolly et al., 1989; Ferrara and Henzel, 1989; Ferrara et al., 1992], an endothelial cellspecific mitogen.

The actions of both bFGF and VEGF are regulated by receptors in the tyrosine kinase family (RTK) [Lee et al., 1989; de Vries et al., 1992]. Binding of the mitogen results in receptor dimerization, activation of the tyrosine kinase domains, and autophosphorylation of the receptors [UIIrich and Schlessinger, 1990]. Phosphorylated tyrosine residues are recognized by adapter molecules via Src homology domains leading to activation of Ras, which triggers a kinase cascade. Ras activation leads to activation of the serine/threonine kinase Raf- 1 which phosphorylates and activates the dual-specificity threonine/tyrosine kinase MEK. MEK in 
turn phosphorylates mitogen-activated protein kinases (MAPK) p44 and p42, resulting in increased expression of early response genes and stimulation of cell proliferation. Both bFGF and VEGF have been shown to activate MAPK in capillary endothelial cells [D'Angelo et al., 1995].

Of equal interest to pathways mediating cell proliferation are the signaling mechanisms which inhibit capillary endothelial cells from entering the cell cycle, thus maintaining their predominant resting state. In endothelial cells, increases in intracellular CAMP have been reported to inhibit basal proliferation [Leitman et al., 1986]. Capillary endothelial cells express a variety of G-protein-coupled receptors, including $\beta$-adrenergic receptors which are positively coupled to adenylyl cyclase. The inhibition of cell proliferation by increased CAMP is mediated through the activation of the cyclic AMPdependent protein kinase (PKA) [Burgering et al., 1993; Cook and McCormick, 1993; Graves et al., 1993; Sevetson et al., 1993; Wu et al., 1993]. In a variety of cell types other than endothelial cells, activation of PKA inhibits activation of MAPK by platelet-derived growth factor (PGDF), epidermal growth factor (EGF), and bFGF [Nilsson and Olsson, 1984; Loesberg et al., 1985; Assender et al., 1992; Cook and McCormick, 1993; van Corven et al., 1993; Hordijk et al., 1994; Chabre et al., 1995]. The target for inhibition by PKA in the MAPK pathway was shown to be Raf-1. Activated PKA phosphorylates Raf-1 on serine 43, inhibiting its kinase activity and blocking the MAPK signaling cascade [Wu et al., 1993; Hafner et al., 1994].

In the current work, we have studied the role of the PKA signaling pathway in the regulation of cell division in the highly differentiated bovine brain capillary endothelial cells (BBE). We have shown that el evation of CAMP levels inhibits VEGF - and bFGF-induced cell proliferation. Pharmacological or $\beta$-adrenergic receptor-mediated elevations in CAMP block mitogen-induced activation of the MAPK signaling pathway. The inhibition, mediated by increased PKA activity, blocks Raf-1 activity. Furthermore, basal PKA activity constitutively suppresses activation of Raf-1/MAPK. These data support an important physiological role for the CAMP signaling pathway in the regulation of capillary endothelial cell proliferation.

\section{METHODS \\ Cell Culture}

Bovine brain capillary endothelial (BBE) cells were isolated as previously described [Gospodarowicz and Cheng, 1986]. The cells were grown and serially passaged in low glucose Dulbecco's modified Eagle's medium (DMEM) supplemented with $10 \%$ calf serum, $2 \mathrm{mM}$ L-glutamine, and antibiotics (100 units of penicillin/ streptomycin per milliliter) and $2.5 \mathrm{mg}$ of Fungizone per milliliter). Basic FGF (bFGF) (Promega, Madison, $\mathrm{WI}$ ) was added ( $1 \mathrm{ng} / \mathrm{ml}$ ) to the cultures every 2 days. Experiments were initiated with confluent cells between passages 5 and 13.

\section{N A Synthesis}

Cells were plated at $1 \times 10^{4}$ per $35 \mathrm{~mm}$ culture dish in $1 \mathrm{ml}$ of incubation medium, serum-starved in DMEM containing $0.5 \%$ calf serum for $24 \mathrm{~h}$. Cells were then stimulated for another $24 \mathrm{~h}$ with bFGF $(1 \mathrm{ng} / \mathrm{ml})$ in the presence or absence of different concentrations of pharmacological agents and $0.6 \mu \mathrm{Ci}\left[{ }^{3} \mathrm{H}\right]$ thymidine/well (20.1 Ci/mmol) (DuPont NEN, Boston, MA) was added for the last $4 \mathrm{~h}$. The reactions were terminated after $24 \mathrm{~h}$ by addition of $5 \%$ trichoroacetic acid following solubilization with $0.25 \mathrm{~N} \mathrm{NaOH}$ as described [Maione et al., 1990]. Forskolin (Sigma, St. Louis, MO) and H-89 (N-[2-(p-bromocinnamylamino)ethyl]-5isoquinolinesulfonamide) (BIOMOL. Res. Lab. Inc, Plymouth Meeting, PA) were sol ubilized in dimethyl sulfoxide (DMSO), 8-Bromo-CAMP (Sigma) was solubilized in deionized water, and 3-isobutyl-1-methylxanthin (IBMX) (Calbiochem, San Diego, CA) was dissolved in DME M containing $0.5 \%$ calf serum. $\left[{ }^{3} \mathrm{H}\right.$ ] thymidine incorporation was measured by liquid scintillation counting.

\section{CAM P Studies}

Cells were plated at $5 \times 10^{5}$ cells per $35 \mathrm{~mm}$ dish in six-well plates in DMEM containing 1 $\mathrm{ng} / \mathrm{ml}$ bFGF. Prior to each experiment, cells were serum-starved by incubation in DMEM containing $0.5 \%$ calf serum for $24 \mathrm{~h}$. Cells were washed with $3 \mathrm{ml}$ of fresh medium and then cultured with various concentrations of IBMX, forskolin, or isoproterenol (Sigma) alone or in combination for different times as indicated. At the end of incubation period, the medium was discarded, and the cells were lysed in $0.25 \mathrm{ml}$ ice-cold $0.1 \mathrm{~N} \mathrm{HCL}$ and immediately frozen on 
dry ice. Subsequently, the cells were sonicated (10 s), incubated at $4^{\circ} \mathrm{C}$ for $48 \mathrm{~h}$, and centrifuged (2,000 $\mathrm{g}$ for $30 \mathrm{~min})$, and the supernatants were stored at $-20^{\circ} \mathrm{C}$ until radioimmunoassayed for CAMP.

\section{CAM P RIA}

CAMP for cell extracts was determined by RIA [Brooker et al., 1979] in triplicate, using rabbit anti-CAMP polyclonal antiserum AB505 (Chemicon, Temecula, CA) and 2'-O-monosuccinyl-CAMP tyrosyl methyl ester (Sigma) as radioligand, after acetylation of the samples with triethylamine-acetic anhydride (2:1). All samples from an experiment were analyzed in the same assay. The limit of detection was 10 $\mathrm{fmol} / \mathrm{ml}$, and the intraassay coefficient of variation was $2.8 \%$.

\section{Preparation of BBE Plasma Membranes}

Membranes were prepared by nitrogen cavitation as described [Ross et al., 1977]. BBE cells were harvested at a density of $5-7 \times 10^{7} / \mathrm{ml}$ by low speed centrifugation and were washed twice at room temperature in phosphate buffered saline (PBS). Subsequent steps were performed at $4^{\circ} \mathrm{C}$. Cells were suspended to $12 \times 10^{7} / \mathrm{ml}$ in $250 \mathrm{mM}$ sucrose, $20 \mathrm{mM}$ Tris- $\mathrm{HCl}(\mathrm{pH} 7.5)$, $1.5 \mathrm{mM} \mathrm{M} \mathrm{gCl}, 3 \mathrm{mM}$ benzamidine $\mathrm{HCl}$ (Sigma), $1 \mu \mathrm{M}$ leupeptin (Boehringer-Mannheim, Indianapolis, I N), $10 \mu \mathrm{M}$ Pefabloc (Boehringer-Mannheim), and $2 \mu \mathrm{g} / \mathrm{ml}$ soybean trypsin inhibitor (Sigma) and were lysed by rapid decompression after equilibration for 20 min with $\mathrm{N}_{2}$ at $800 \mathrm{psi}$ in a Parr cell disruption bomb (Parr Instrument Co., Moline, IL). One-eightieth volume $100 \mathrm{mM}$ EGTA was added to the lysate before centrifugation for $10 \mathrm{~min}$ at $900 \mathrm{~g}$. Thesupernatant was centrifuged for $30 \mathrm{~min}$ at $47,800 \mathrm{~g}$, and the pellet was resuspended and homogenized in $20 \mathrm{mM}$ Tris- $\mathrm{HCl}$ (pH 7.5), $1 \mathrm{mM}$ EDTA, $1 \mathrm{mM}$ dithiothreitol (DTT), $4 \mu \mathrm{g} / \mathrm{ml}$ aprotinin (Sigma).

\section{Adenylyl Cyclase Assay}

Membranes $(0.3 \mathrm{mg} / \mathrm{ml})$ were incubated for $15 \mathrm{~min}$ at $30^{\circ} \mathrm{C}$ in a volume of $50 \mu$ containing $50 \mathrm{mM}$ Tris (pH 8), $1 \mathrm{mM}$ EDTA, $2.5 \mathrm{mM} \mathrm{MgCl} 2$, $2 \mathrm{mM} \beta$-mercaptoethanol, $1 \mu \mathrm{g} / \mathrm{ml}$ bovine serum albumin, $10 \mathrm{mM}$ creatine phosphate (Sigma), 100 units of creatine phosphokinase per milliliter (Sigma), $1 \mathrm{mM}$ adenosine 3'-5'cyclic monophosphate (CAMP) (Sigma), $0.4 \mathrm{mM}$ ATP, $0.1 \mu \mathrm{Ci}\left[{ }^{3} \mathrm{H}\right]$ cAMP $(25-40 \mathrm{Ci} / \mathrm{mmol})(\mathrm{Du}-$
Pont NEN $), 4 \mu \mathrm{Ci}[\alpha-32 \mathrm{P}] \mathrm{ATP}(3,000 \mathrm{Ci} / \mathrm{mmol})$ (DuPont NEN), and various activators. Reactions were terminated by addition of $1 \mathrm{ml}$ of $0.5 \%$ SDS, and CAMP was purified as described [Salomon et al., 1974]. Under these conditions, the rate of CAMP synthesis was constant during the time of incubation.

\section{Cell Stimulation and Preparation of Cell Extracts}

Confluent cell cultures were dispersed and plated at the density of $5 \times 10^{5}$ cells per $60 \mathrm{~mm}$ culture plate (one plate per condition) in DMEM containing $1 \mathrm{ng} / \mathrm{ml}$ bFGF. Twenty-four hours after plating, cells were serum-starved in DMEM containing $0.5 \%$ calf serum for $48 \mathrm{~h}$. Cells were left untreated or treated with different concentrations of $\mathrm{H} 89,1 \mathrm{mM}$ 8-bromoCAMP, $50 \mu \mathrm{M}$ forskolin, or $10 \mu \mathrm{M}$ isoproterenol for different times at $37^{\circ} \mathrm{C}$ as indicated. Cells were then incubated with $1 \mathrm{nM}$ recombinant human VEGF 165 (VEGF; Genentech, So. San Francisco, CA) or $0.5 \mathrm{nM}$ bFGF for $5 \mathrm{~min}$. We previously demonstrated that MAPK activation was maximum at $5 \mathrm{~min}$ (D'Angelo et al., 1995].

\section{Assay for MAPK Activity}

Cells wereanalyzed for MAPK activity according to published procedures [D'Angelo et al., 1995]. Briefly, equal quantities of cell lysates were immunoprecipitated with an MAPK polyclonal antiserum which recognized both MAPK p44 and p42 (Erk1-CT) and immune complexes purified by protein A-sepharose. The precipitates were incubated with myelin basic protein (MBP) and [ $\left.\gamma^{-32 P}\right]$ ATP and reaction products resolved by SDS-PAGE (12\% gels). Radioactivity incorporated into the MBP band was quantitated by phosphorimaging.

\section{Assay for Raf-1 Activity}

Proteins from equal quantities of cell lysates from control or stimulated BBE cells were immunopreci pitated with $10 \mu$ of Raf- 1 polyclonal antiserum (Raf-1 [C12]) for $3 \mathrm{~h}$ at $4^{\circ} \mathrm{C}$, and protein A-Sepharose beads were added for the last $60 \mathrm{~min}$. Immune complexes were washed twice in lysis buffer and once in kinase buffer (50 mM Tris (pH 7.5), $100 \mathrm{mM} \mathrm{NaCl}, 10 \mathrm{mM}$ $\mathrm{MgCl}_{2}$, and $1 \mathrm{mM}$ DTT). The precipitates were resuspended in $30 \mu \mathrm{l}$ kinase assay buffer containing $0.25 \mu \mathrm{g}$ of recombinant baculovirusexpressed catalytically inactive MEK-B [Mac- 
donald et al., 1993], $50 \mu \mathrm{M}$ ATP, and $5 \mu \mathrm{Ci}$ of [ $\gamma$-32P]ATP. To determine the endogenous Raf- 1 activity, we incubated the immunocomplexes in the same buffer in the absence of MEK-B. Samples were incubated for $30 \mathrm{~min}$ at $22^{\circ} \mathrm{C}$ and the assay terminated by the addition of hot $4 \times$ SDS-PAGE sample buffer ( $10 \mu \mathrm{l})$ followed by boiling for $5 \mathrm{~min}$. Reaction products were resolved by SDS-PAGE ( $12 \%$ gels). Gels were dried and subjected to autoradiography. The radioactivity incorporated into the MEK-B band was quantitated by phosphorimaging. To determine the endogenous Raf- 1 activity, we incubated the immunocomplexes in the same buffer in the absence of MEK-B. We verified that Raf-1 immunoprecipitates were not contaminated with MAPK since immunoprecipitates were unable to phosphorylate MBP.

\section{RESU LTS \\ Inhibition of Cell Proliferation by Pharmacologically Elevating cAMP}

In view of previous reports showing that sustained el evation of CAMP inhibits the proliferation of many cell types [for review see Hordijk et al., 1994], we conducted experiments to investigate the effect of el evated CAMP levels on the stimulation of proliferation of BBE cells by bFGF and VEGF. BBE cells were treated with 8-bromo-CAMP, the permeable CAMP analogue, forskolin, a stimulator of adenylyl cyclase, and IBMX, the nonselective phosphodiesterase inhibitor. Treatment of serum-deprived BBE cells with bF GF caused a significant increase in [ ${ }^{3} \mathrm{H}$ ] thymidine incorporation (Fig. $1 \mathrm{~A}-\mathrm{C}$ ). Forskolin inhibited the 2.2-fold bFGF-induced stimulation of DNA synthesis in a dose-response fashion $\left(I_{50}=50 \mu \mathrm{M}\right)$, with a total reversal of the stimulatory action of bFGF at a concentration of $100 \mu \mathrm{M}$ (Fig. 1A). Similarly, forskolin also inhibited in a dose-response manner the twofold increase in BBE cell proliferation stimulated by VEGF (data not shown). Essentially the same results were obtained using 8-bromoCAMP, which completely reversed the bFGFinduced BBE cell proliferation at $1 \mathrm{mM}$ (Fig. 1B). IBMX was also capable of inhibiting bF GF stimulated BBE cell proliferation in a dosedependent manner $\left(E_{50}=0.5 \mathrm{mM}\right)$ (Fig. 1C). IBMX treatment at the highest concentration $(0.5 \mathrm{mM})$ showed a long-term cytotoxic effect. Treatment of cells with increasing concentrations of the $\beta$-adrenergic agonist, isoproterenol, from 0.01-1 $\mu \mathrm{M}$ had a modest effect on the FGF-induced increase in cell proliferation, with the $1 \mu \mathrm{M}$ concentration inhibiting 34\% of the stimulation (data not shown).

\section{Effect of Isoproterenol on Intracellular CAMP Levels and on Adenylyl Cyclase Activity}

Various types of endothelial cells were shown to express $\beta_{2}$-adrenergic receptors positively coupled to adenylyl cyclase [Bacic et al., 1992; Benschop et al., 1994; Zhou et al., 1995]. Treatment of BBE cells with different concentrations of isoproterenol alone had no significant effect on intracellular CAMP levels. Since this was likely due to the rapid hydrolysis of CAMP by phosphodiesterases, we repeated the isoproterenol study in the presence of IBMX. In the presence of $0.5 \mathrm{mM}$ IBMX, the effect of submaximal doses of isoproterenol on the intracellular concentration of CAMP was greatly potentiated, so that $0.01 \mu \mathrm{M}$ isoproterenol caused a tenfold increase in CAMP levels (Fig. 2A). Similarly, the modest elevation in CAMP observed following forskol in treatment was dramatically increased by IBMX (data not shown). The potentiation of low doses of both isoproterenol and foskolin is consistent with the action of IBMX to block the metabolism of CAMP, resulting in the prolonged increase in CAMP [Kaur et al., 1992].

We asked whether occupany of endogenously expressed $\beta_{2}$-adrenergic receptors would activate adenylyl cyclase. BBE cells membranes were incubated for $15 \mathrm{~min}$ with $10 \mu \mathrm{M}$ of $1 \mathrm{nM}$ VEGF in the presence of $50 \mu \mathrm{M}$ GTP and of 50 $\mu \mathrm{M}$ forskolin. As shown in Figure 2B, forskolin and isoproterenol were capable of activating adenylyl cyclase in BBE cells, whereas VEGF had no effect. In the presence of GTP, isoproterenol caused a doubling in adenylyl cyclaseactivity over that measured in the presence of GTP alone, while forskolin induced a more modest increase.

\section{Role of PKA in Inhibition of BBE Cell Proliferation by Forskolin}

To investigate whether the inhibitory effect of elevating CAMP was mediated via the activation of PKA, we measured the effect of $\mathrm{H} 89$, a specific inhibitor of PKA [Chijiwa et al., 1990], on the proliferation of BBE cells. BBE cells were incubated with bFGF and forskolin in the presence or absence of $\mathrm{H} 89$. Confirming earlier results, treatment with 20 and $50 \mu \mathrm{M}$ forskolin significantly inhibited the bF GF-induced proliferative effect by 20 and $60 \%$, respectively. Treat- 


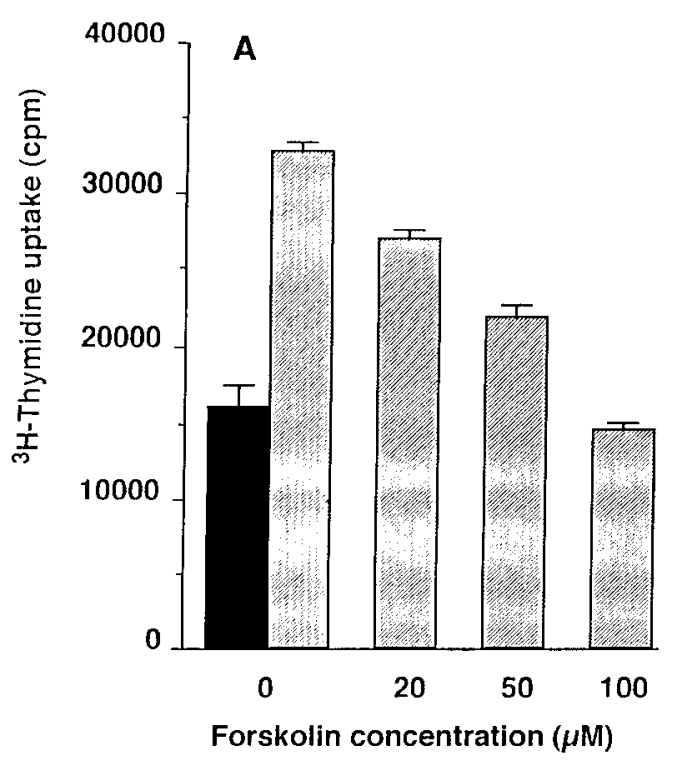

basal bFGF
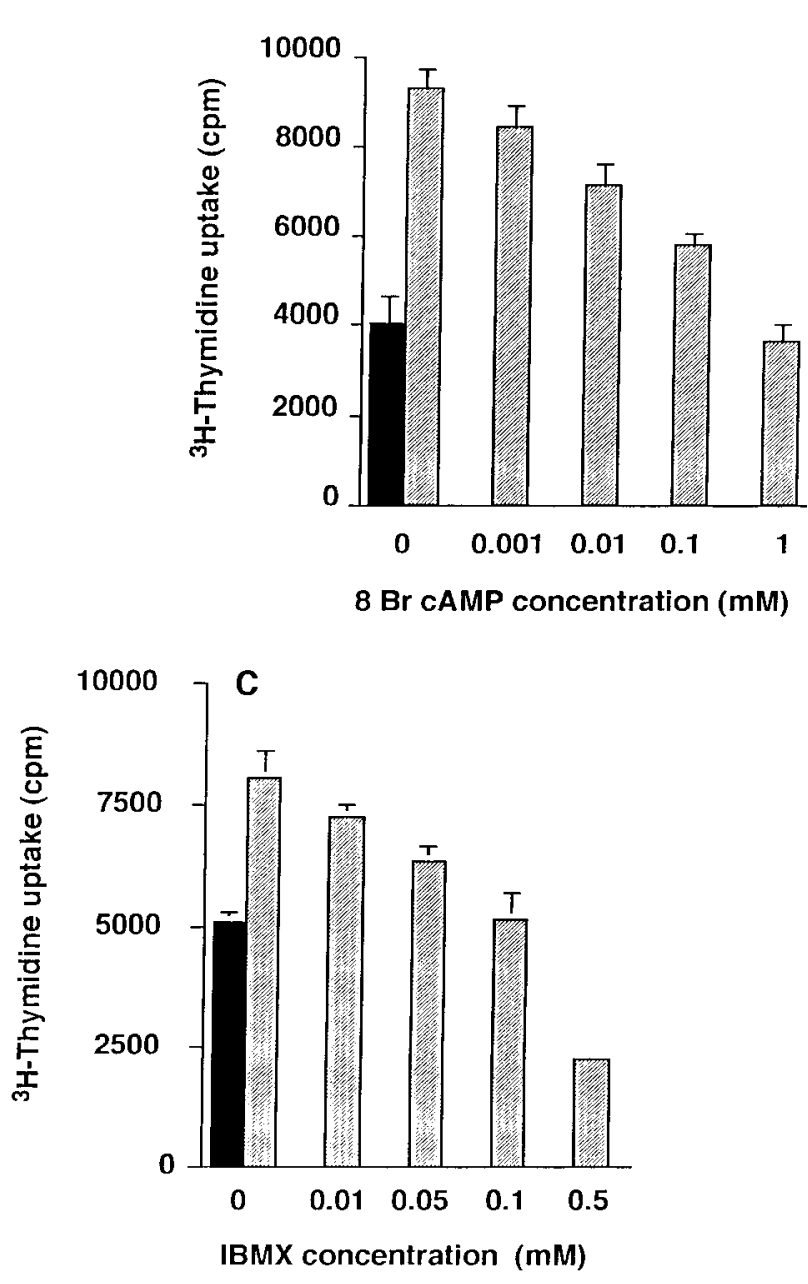

Fig. 1. Inhibition of bFGF-induced DNA synthesis in BBE cells by pharmacological agents increasing CAMP. Serum-deprived BBE cells were left untreated or stimulated with $50 \mathrm{pM}$ of bFG F in the presence of increasing concentrations of the following agents: (A) forskolin, (B) 8-bromo-cAMP, and (C) IBMX. Results

ment with either 1 or $10 \mathrm{nM}$ H 89 reversed the inhibitory effect of both concentrations of forskolin on the bFGF-induced stimulation (Fig. 3). However, treatment with $\mathrm{H} 89$ alone did not affect either the basal or the bFGF-stimulated cell proliferation.

\section{Inhibition of VEG F-Stimulated MAPK by Elevated cAM P Intracellular Levels}

We had recently demonstrated that the proliferative action of VEGF was mediated, at least in part, by activation of the MAPK signaling pathway. We have previously observed that VEGF was a potent activator of both MAPK p44 and p42. In addition, our data also suggested that MAPK p44 was the most abundant and the predominantly activated protein follow- are expressed as mean counts per minute $(\mathrm{cpm}) \pm \mathrm{SD}$ of triplicates of $\left[{ }^{3} \mathrm{H}\right]$ thymidine incorporated into acid-precipitable material. Similar results were observed in four independent experiments.

ing VEGF or bFGF treatment [D'Angelo et al., 1995]. We tested if elevation of theintracellular CAMP level by treatment with 8-bromo-cAMP, isoproterenol or forskolin affected activation of theVEGF signaling pathway in BBE cells. Confirming our earlier observations [D'Angelo et al., 1995], VEGF induced a two to threefold increase in enzyme activity (Fig. 4). Brief treatment of the cells with 8-bromo-cAMP blocked VEGF-induced activation of MAPK by $80 \%$, whileincubation with 8-bromo-CAMP al one had no effect compared to the control (Fig. 4A,B). A complete inhibition of VEGF-induced activation of MAPK was observed in cells pretreated for $5 \mathrm{~min}$ with $10 \mu \mathrm{M}$ isoproterenol (Fig. 4C) or $10 \mathrm{~min}$ with $50 \mu \mathrm{M}$ forskolin (Fig. 7). However, neither isoproterenol nor forskolin produced 
A

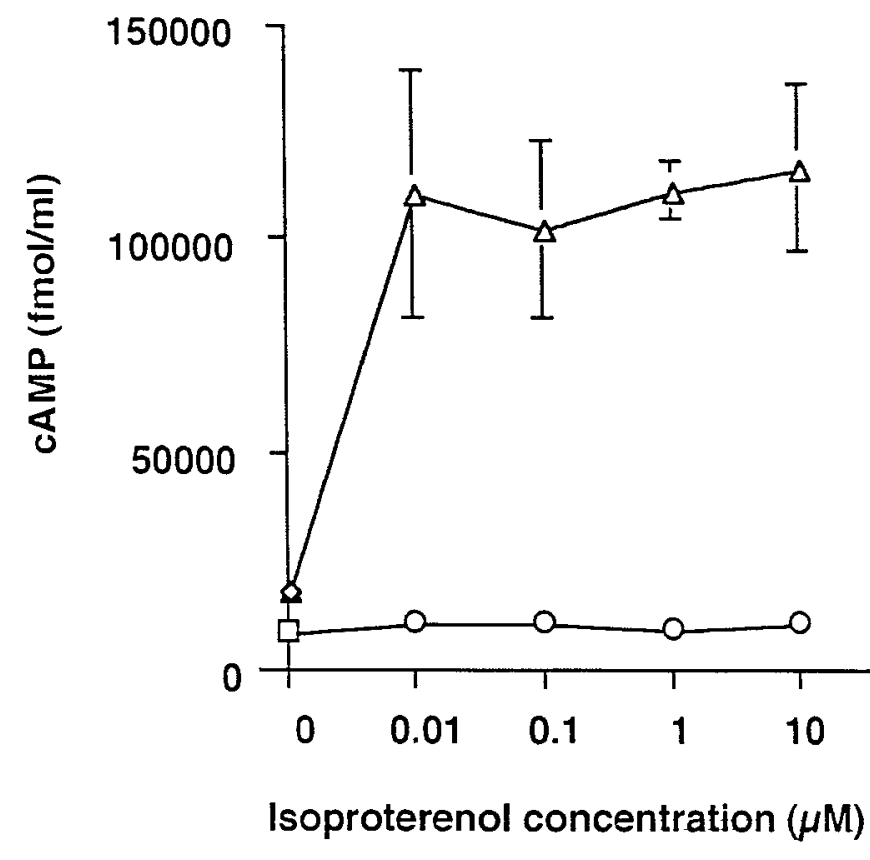

$\longrightarrow$ basal

............ IBMX

-...-.... Isoproterenol

--- $\triangle$ Isoproterenol + IBMX

B

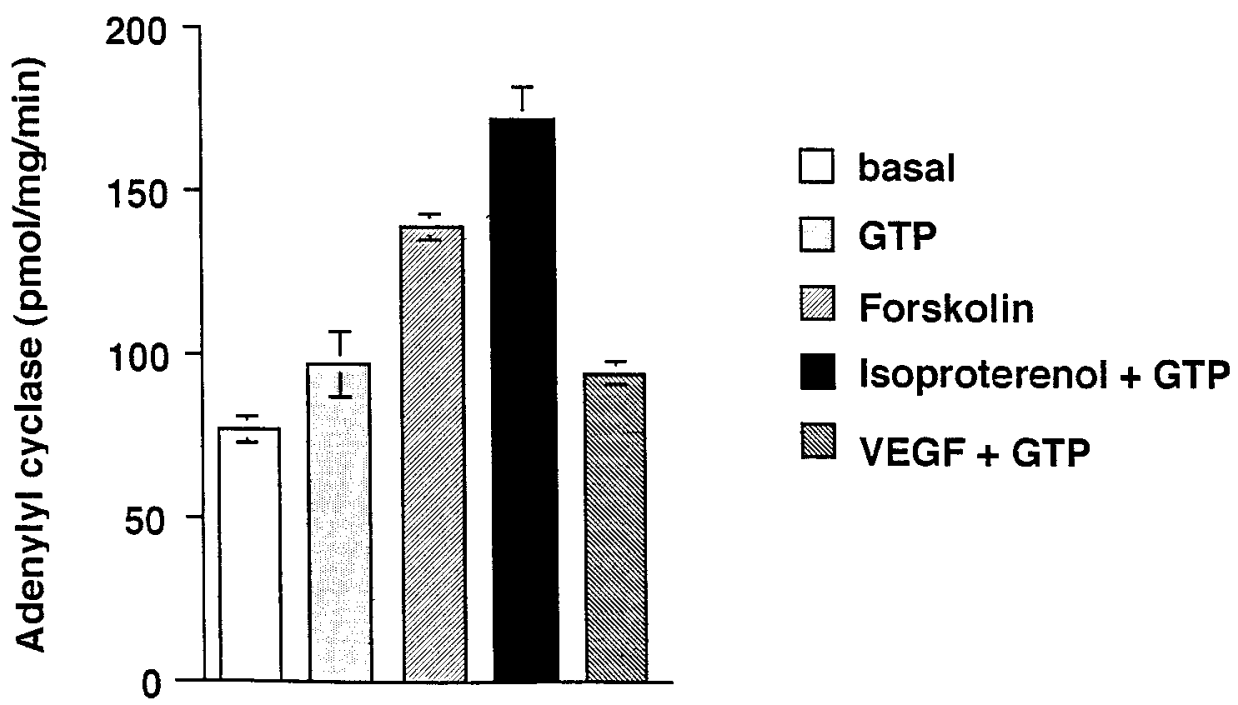

Fig. 2. A: Effect of isoproterenol on intracellular CAM P levels. For dose-response studies, cells were cultured with increasing concentrations of isoproterenol for $10 \mathrm{~min}$. Comparisons were also made between cells treated with isoproterenol alone or preincubated with IBMX $(0.5 \mathrm{mM})$ for 30 min prior to addition of isoproterenol. Levels of CAM P were determined by radioimmunoassay. Values represent the mean \pm SEM of triplicates. Similar results were obtained in three independent experiments.
B: Effect of GTP, forskolin, isoproterenol, and VEG F on adenylyl cyclase activity. BBE cell plasma membrane preparations were left untreated or treated with $50 \mu \mathrm{M}$ forskolin, $50 \mu \mathrm{M} \mathrm{GTP}, 10$ $\mu \mathrm{M}$ isoproterenol $+50 \mu \mathrm{M}$ GTP, and $1 \mathrm{nM}$ VEGF $+50 \mu \mathrm{M}$ GTP. Values for adenylyl cyclase activity are the mean \pm SE of triplicates. Similar results were obtained in three independent experiments. 

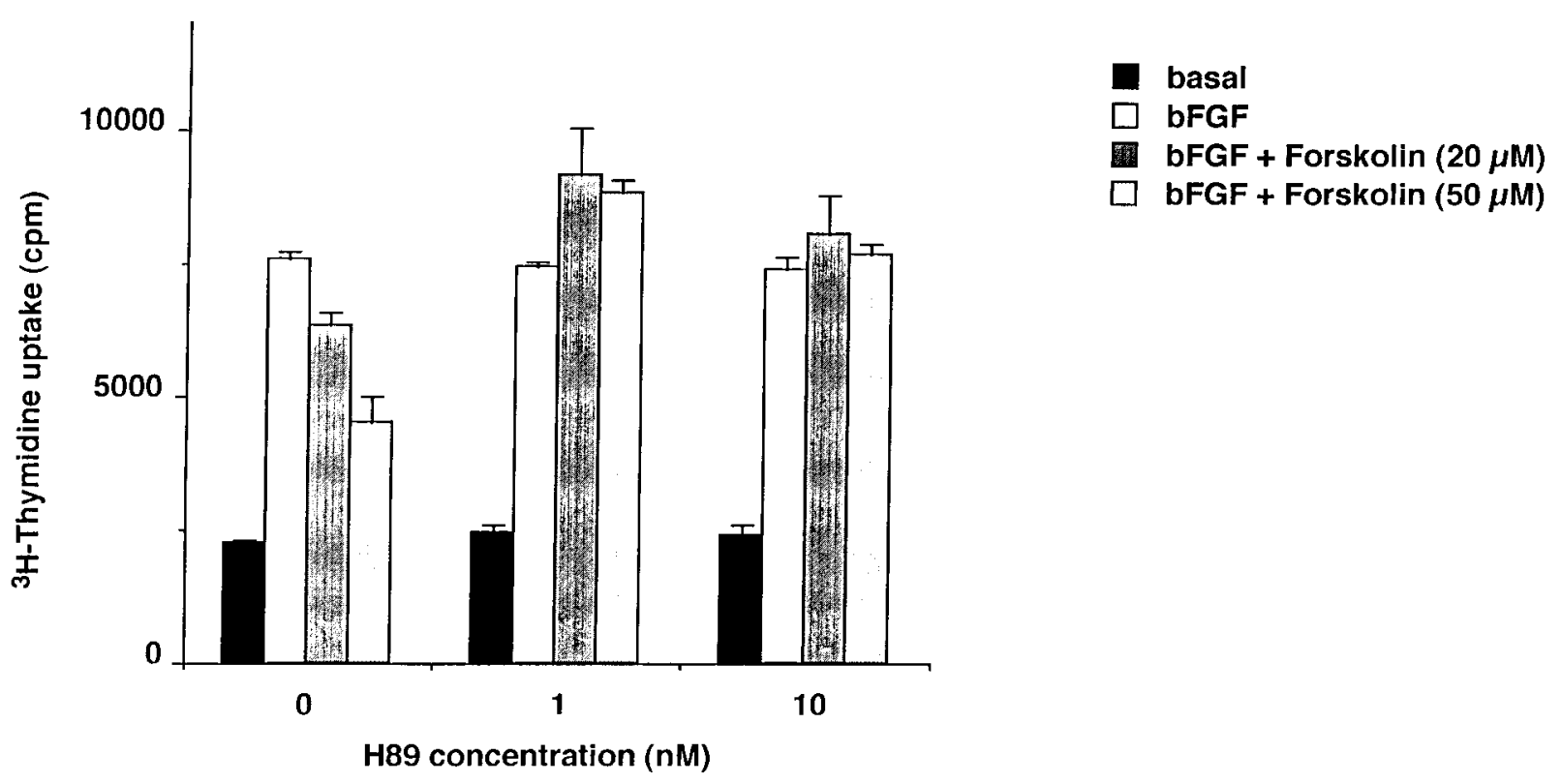

Fig. 3. Blockade by $\mathrm{H} 89$ of the antimitogenic effect of forskolin on bFGF-stimulated cells. BBE cells were left untreated or stimulated with $50 \mathrm{pM}$ of bFGF in the presence 20 or $50 \mu \mathrm{M}$ forskolin. $\mathrm{H} 89$ was added to the culture medium at the indi-

any change in the basal MAPK activity. Thus, CAMP-induced inhibition of BBE cell proliferation correlates with abrogation of growth factor activation of the MAPK cascade.

\section{Inhibition of VEG F-Induced Raf-1 Activation by 8-Bromo-cAM P}

Raf-1 is a serine/threonine kinase whose activation by growth factors results in the downstream activation of MAPK [Dent et al., 1992; Howe et al., 1992; Kyriakis et al., 1992]. It was known that treatment of BBE cells with bFGF and VEGF activated MAPK [D'Angelo et al., 1995], but it had not been shown that this was preceded by activation of Raf-1. Thus, we asked if treatment of BBE cells with VEGF and bFGF activates Raf-1. Raf-1 activity was evaluated by an in vitro kinase assay in which immunoprecipitated Raf-1 was incubated with recombinant, inactive MEK-B, a physiological substrate of Raf-1. Treatment of cells with both VEGF or bFGF caused an approximately twofold activation of Raf-1 (Figs. 5, 6).

Since activation of PKA has been shown to inhibit mitogen-induced Raf-1 activation [Wu et al., 1993; Hafner et al., 1994], wethen tested the effect of PKA activation on VEGF - and bF GF -induced Raf-1 activity. Pretreatment with 8-bromo-CAMP reduced the stimulatory effect of VEGF on Raf-1 activity by $80 \%$ (Fig. 5), and

cated concentrations. Results are expressed as mean counts per minute $(\mathrm{cpm}) \pm \mathrm{SD}$ of triplicates of $\left[{ }^{3} \mathrm{H}\right]$ thymidine incorporated into acid-precipitable material. Similar results were obtained in four independent experiments.

incubation with forskolin inhibited Raf-1 stimulation by bFGF by $80 \%$ (Fig. 6 ). In control cells or cells stimulated either with 8-bromo-cAMP or forskolin alone, no change in Raf-1 activity is observed. These results were consistent with the hypothesis that 8-bromo-cAMP was acting to block Raf-1 [Burgering et al., 1993; Sevetson et al., 1993; Wu et al., 1993].

\section{Elevated cAMP Inhibits Raf-1/MAPK Activation via PKA}

To test whether activation of PKA was necessary for the inhibition of the Raf/MAPK signaling pathway caused by elevations in CAMP, we asked if treatment with $\mathrm{H} 89$ would block the inhibitory effect of forskolin on the VEGFinduced activation of MAPK (Fig. 7). Treatment with VEGF caused a threefold stimulation of MAPK activity which was inhibited by the addition of forskolin. Treatment with $\mathrm{H} 89$ alone stimulated MAPK to the same degree as VEGF and reversed the inhibitory effect of forskolin on VEGF-induced activation of MAPK. Similarly, as shown in Figure 6, treatment with $\mathrm{H} 89$ alone also stimulated basal Raf-1 activity to a level comparable to that seen with bFGF. The stimulation of Raf-1 by $\mathrm{H} 89$ was also observed in the presence of forskolin. These data support the hypothesis that activation of PKA is necessary for the inhibition of mitogen-induced acti- 
A
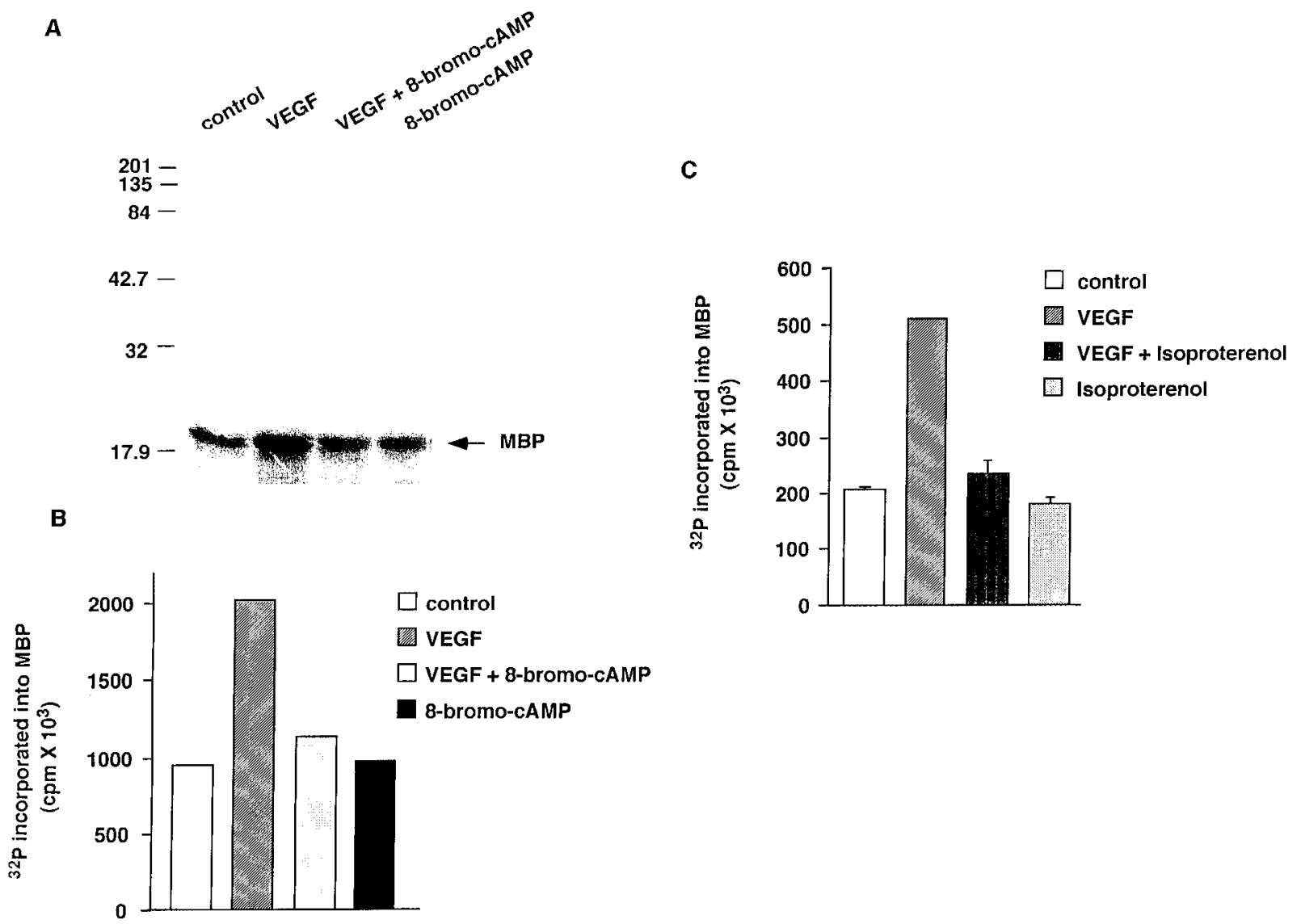

a substrate. Reaction mixtures were resolved by SDS-PAGE ( $12 \%$ gels) and analyzed by autoradiography. The position of molecular size markers ( $\mathrm{KDa}$ ) are indicated. B: Q uantitation of radioactive phosphate incorporated into $M B P$ in $A$ was evaluated using a phosphorimager. The level of incorporation observed with VEG F was designated as $100 \%$. Similar results were obtained in two other independent experiments. C: MAPK activity was determined as above. Values represent the mean \pm SE of three independent experiments.

vation of Raf-1 and MAPK. Furthermore, the stimulation of both Raf-1 and MAPK by treatment with $\mathrm{H} 89$ alone suggests that PKA activity is sufficient, even in the basal state, to suppress signaling via this pathway.

\section{DISCUSSION}

These findings support an important regulatory role for the CAMP signaling pathway in the control of proliferation of capillary endothelial cells. Elevations in CAMP levels can inhibit the ability of BBE cells to enter the cell cycle, since treatment of BBE cells with forskolin, 8-bromoCAMP, and IBMX inhibits the proliferative actions of bFGF and VEGF. The modest inhibitory effect of the long-term treatment with isoproterenol on the mitogenic action of bFGF

is consistent with the rapid desensitization of $\beta$-adrenergic receptors by agonists [ $\mathrm{N}$ antel et al., 1995]. Our data is in complete agreement with previous reports demonstrating that increases in CAMP are inhibitory for proliferation of many cell types [Pastan et al., 1975; L eitman et al., 1986]. In smooth muscle cells and fibroblasts, increases in CAMP inhibit the PDGFand EGF-stimulated DNA synthesis and cell proliferation, respectively [Nilsson and Olsson, 1984; Loesberg et al., 1985; Assender et al., 1992; Cook and McCormick, 1993; van Corven et al., 1993; Hordijk et al., 1994].

Intracellular levels of CAMP appear to be tightly regulated by phosphodiesterase activity in BBE cells. Small if any changes in intracellular CAMP are observed following treatment with 
A

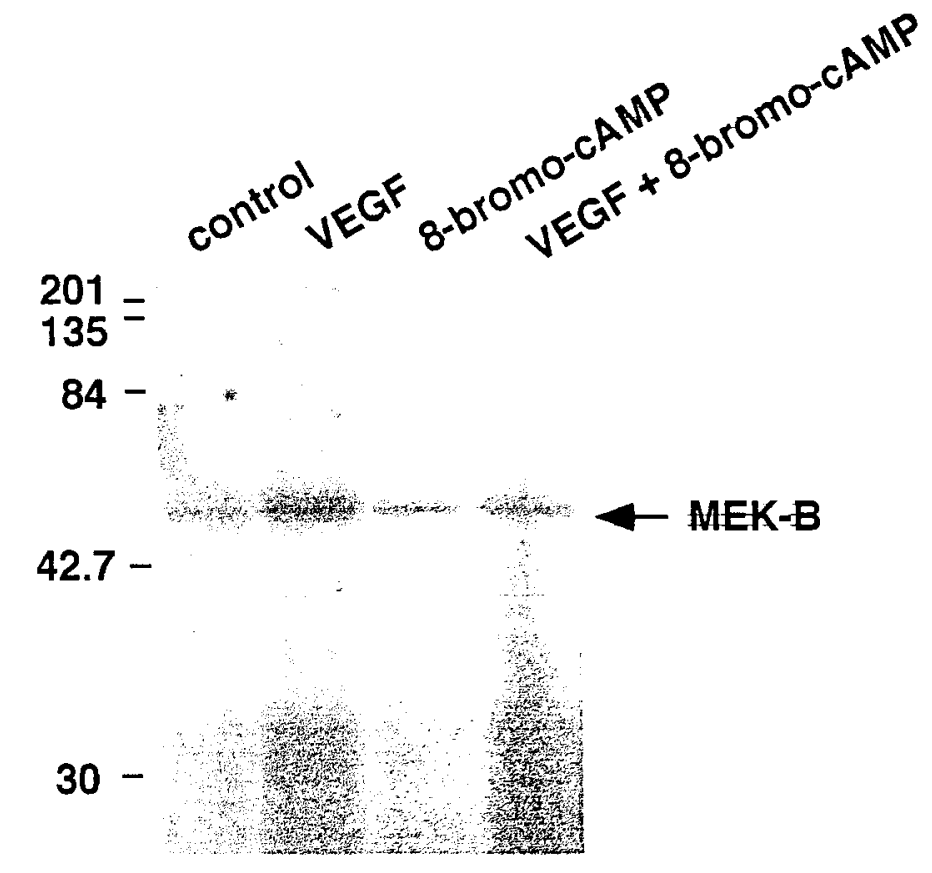

B

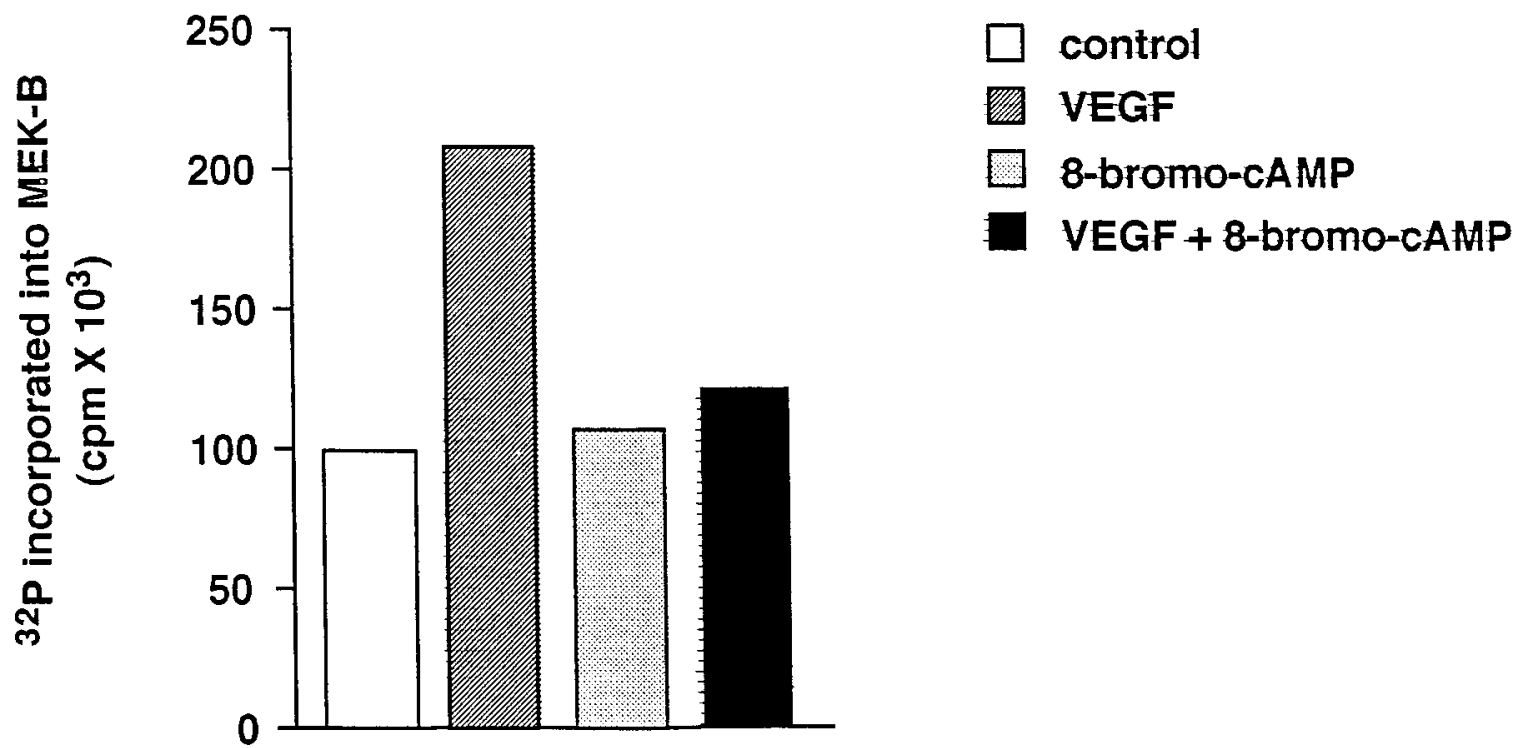

Fig. 5. Inhibition of Raf-1 activity by 8-bromo-CAMP. A: BBE cells were left untreated or stimulated with $1 \mathrm{nM}$ VEGF, $1 \mathrm{mM}$ 8-bromo-cAMP, or $1 \mathrm{nM}$ VEGF $+1 \mathrm{mM}$ 8-bromo-cAMP. Cells were treated with 8-bromo-cAM $P$ for 10 min prior to addition of VEGF for $5 \mathrm{~min}$. Proteins from cell lysates were immuniprecipitated with anti-Raf-1 polyclonal antiserum, and kinase activity of immune complexes was assayed using MEK-B as a substrate.
Samples were resolved by SD S-PAGE ( $10 \%$ gels) and visualized by autoradiography. Sizes are indicated in kilodaltons. B: The radioactivity incorporated into MEK-B shown in A was quantitated by phosphorimaging. The level of incorporation observed with VEGF was designated as $100 \%$. Similar results were obtained in three additional studies. 
A

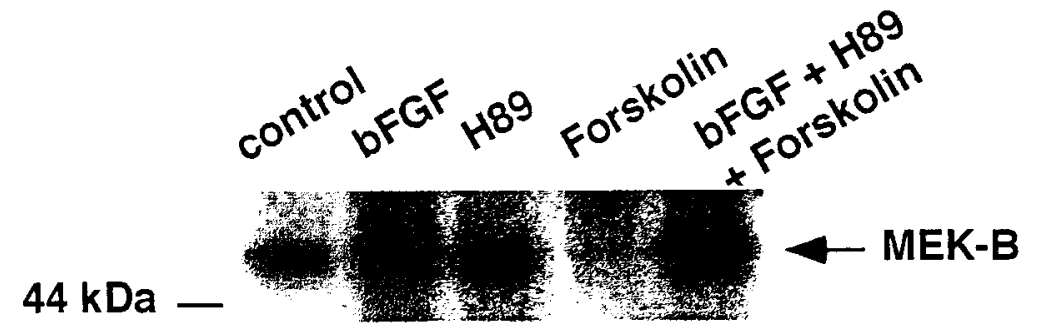

B

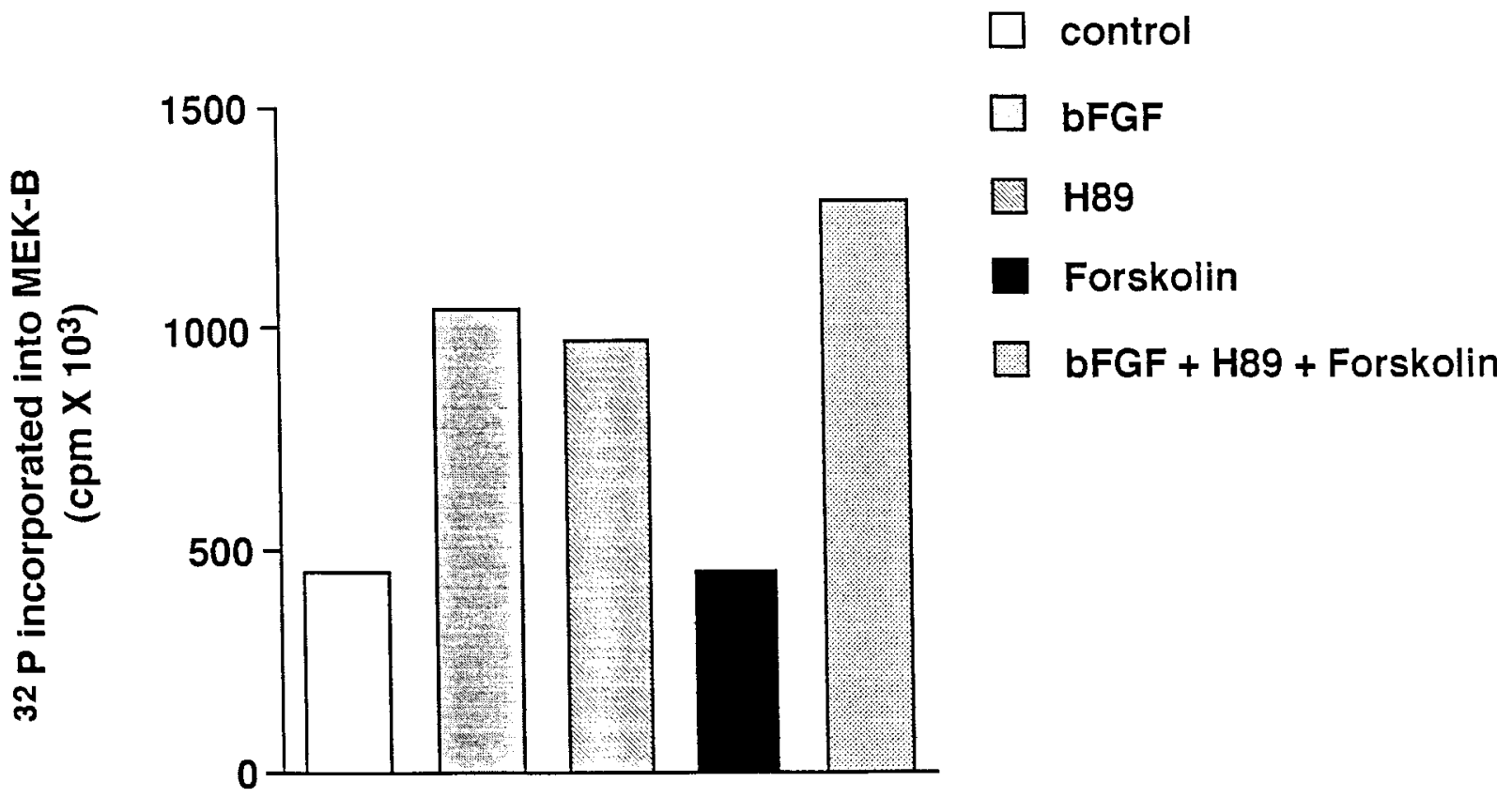

Fig. 6. Blockade of forskolin-inhibited Raf- 1 activity by $\mathrm{H} 89$ pretreatment. A: BBE cells were left untreated or preincubated with $10 \mu \mathrm{M} \mathrm{H} 89$ for 60 min prior to a 5 min stimulation with 0.5 nM bFGF. Forskkolin $(50 \mu \mathrm{M})$ was added 5 min prior to treat-

isoproterenol or forskolin; however, these responses are greatly potentiated by the presence of the phosphodiesterase inhibitor, IBMX. Similar observations were made in cultured bovine aortic endothelial cells (BAEC); however, this was not seen with human umbilical vein, human adipose microvascular, and pig pulmonary artery endothelial cells in culture [Manolopoulos et al., 1995]. That pharmacological agents suppress cell proliferation without causing a large change in intracellular CAMP levels, ar- ment with bFGF. B: Raf-1 activity shown in A was assayed and quantitated as previously described. Similar results were observed in two additional independent experiments.

gues that changes in CAMP in discrete intracellular compartments are sufficient to regulate signaling events. Thehigh level of phosphodiesterase supports the importance of the CAMP signaling pathway, necessitating maintenance of a precise balance in the synthesis and hydroIysis of CAMP.

The inhibitory action of el evated CAMP levels on cell proliferation is mediated by activation of PKA, since it is blocked by treatment with $\mathrm{H} 89$. $\mathrm{H} 89$ has been shown to specifically inhibit PKA 
A

B

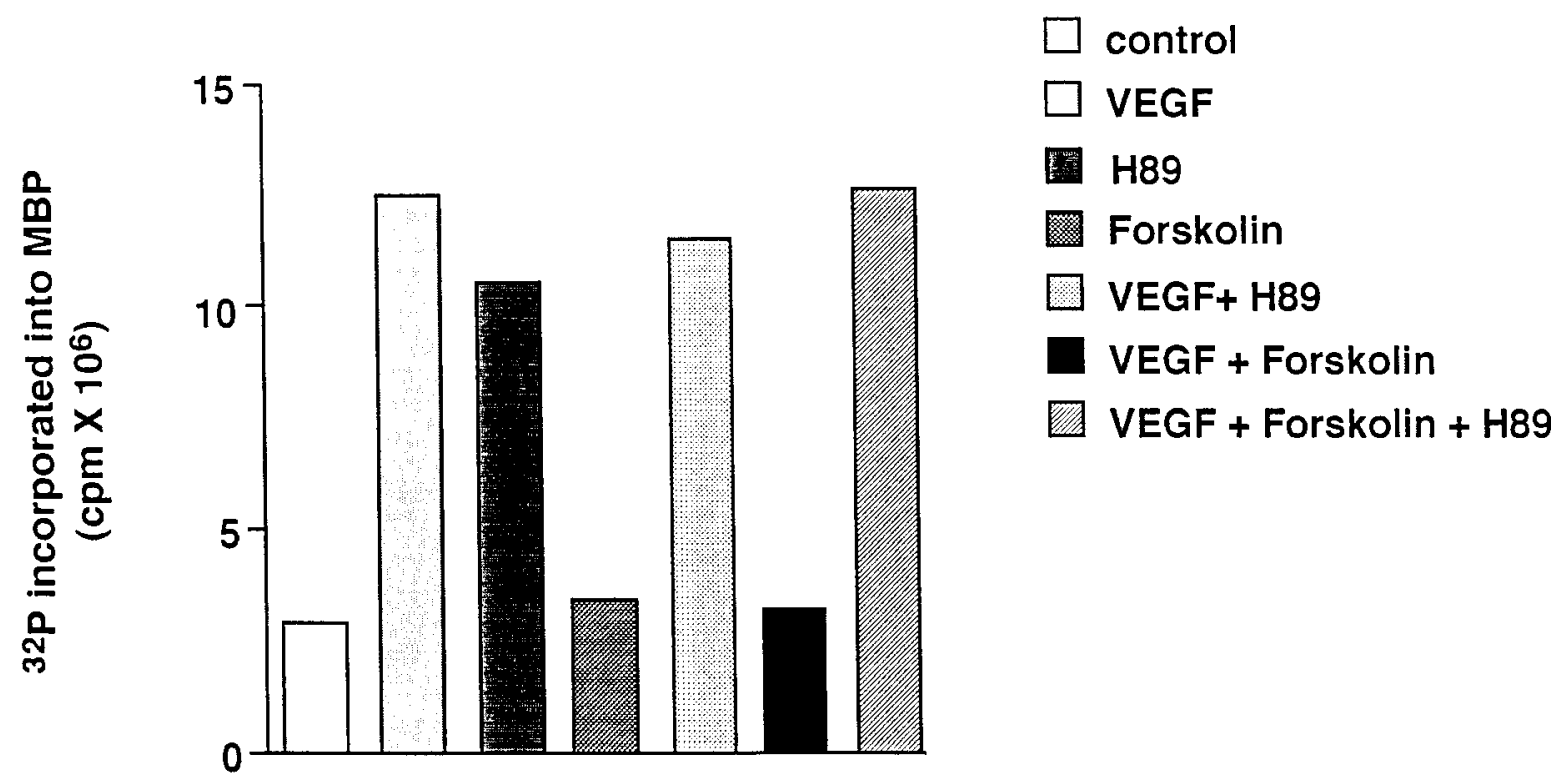

Fig. 7. Blockade of the inhibitory effect of forskolin on VEG F-induced M APK by H 89 pretreatment. A: BBE cells were left untreated or preincubated with $10 \mu \mathrm{M} \mathrm{H} 89$ for 60 min prior to a 5 min stimulation with $1 \mathrm{nM}$ VEG F. Forskolin (50 $\mu \mathrm{M}$ ) was added 5 min prior to the addition of 1 nM VEG F. B: M APK activity shown in A was assayed and quantitated as previously described. Similar results were obtained in two other independent experiments.

activity in many different cell types [Chijiwa et al., 1990; Barbara and Takeda, 1995; Fujii et al., 1995; Tool and Verhoeven, 1995; Post et al., 1996]. Treatment with $\mathrm{H} 89$ was capable of reversing the inhibition of FGF-induced cell proliferation by forskolin but did not affect the basal rate of cell proliferation. Therefore, removing basal PKA activity was not sufficient to stimulate BBE cells entering the cell cycle.

We have previously demonstrated that the endothelial cell mitogens VEGF and bFGF stimulateBBE cell proliferation [Ferrara et al., 1991] at least in part by activation of the MAPK signaling pathway [D’Angel o et al., 1995]. This pathway has been shown to be important in BBE cells, since selective inhibition of MAPK activation by the antiangiogenic factor 16K PRL blocks the mitogenic action of both VEGF and bFGF [D'Angelo et al., 1995]. We have shown that the serine/threonine kinase Raf-1 is activated upstream of MAPK by VEGF and bFGF. This was important to determine, since MAPK can also be activated via MEK kinase (MEKK), which is independent of Raf-1 activation [LangeCarter et al., 1993]. Moreover, the inhibition of Raf- 1 and MAPK activation by increased levels 
of CAMP is mediated by PKA, since the action of CAMP is blocked by H89. Our results are consistent with a system in which CAMP inhibits growth of BBE cells by inhibiting Raf- 1 activation, although CAMP is also likely to affect cell regulation through other Raf-independent mechanisms [Habener, 1990]. Moreover, similar observations were previously reported in transformed cells stimulated by EGF [Wu et al., 1993]. The blockade of MAPK activation was shown to occur at the level of Raf-1 [Burgering et al., 1993; Cook and McCormick, 1993; LangeCarter et al., 1993; Wu et al., 1993]. Inhibition of Raf- 1 activation is presumably due to phosphorylation of serine 43 by PKA [Wu et al., 1993; Hafner et al., 1994]. Phosphorylation of this residue reduces the affinity of Raf- 1 to associate with Ras-GTP [Wu et al., 1993]. Activation of PKA was shown to phosphorylate Raf-1 both in vitro and in vivo [Wu et al., 1993; Hafner et al., 1994]. However, since in vitro Raf-1 mutants lacking serine 43 are still capable of being inhibited by PKA [Hafner et al., 1994], other phosphorylation sites also appear to be involved.

Treatment with $\mathrm{H} 89$ al one activates the Raf1/MAPK signaling cascade to a similar level to that observed following treatment with bFGF and VEGF. These results suggest that endogenous PKA activity in resting BBE cells is high, and removal of this activity is a potent stimulus for activation of the MAPK signaling cascade. No additive effect was observed in cells treated with both VEGF and H89, suggesting that the Raf-1/MAPK activation is maximal with either treatment. Similarly, no additive or potentiated effect on Raf-1/MAPK activation was observed in BBE cells cotreated with VEGF and PMA, a protein kinase $C$ activator [Nishizuka, 1986; D'Angelo, unpublished observations], again suggesting maximal stimulation by either treatment. However, H89 treatment did not stimulate basal cell proliferation. These apparent paradoxical observations suggest that activation of MAPK is necessary but not sufficient for driving BBE cells into cell cycle. Treatment with VEGF and bFGF results in activation of additional signaling pathways including phospholipase- $\mathrm{C} \gamma$ which also may be necessary for regulation of cell proliferation.

The level of intracellular CAMP/PKA activity represents a potentially important physiological regulator of capillary endothelial cell division. Since isoproterenol treatment induces only a modest increase of adenylyl cyclase activity but completely inhibits MAPK activity, it again appears that small changes in the local concentration of CAMP or transient changes are sufficient to mediate the biological response. The level of PKA activity is regulated by a variety of additional factors, including interleukin-4 (IL4), tumor necrosis factor-al pha (TNF- $\alpha$ ) [Galea et al., 1993], prostaglandin $E_{2}\left(P E_{2}\right)$ [Ida et al., 1994], and histamine [Manolopoulos et al., 1995], further supporting the concept that this pathway is highly regulated in vivo.

In conclusion, these observation indicate that, in BBE cells, PKA may act to attenuate growth factor signaling by inhibiting the activity of Raf-1. The present data demonstrate functional cross-talk between the MAPK and PKA signaling pathways in BBE cells. Furthermore, PKA activity in unstimulated BBE cells appears to block activation of MAPK, since treatment with $\mathrm{H} 89$ stimulates MAPK to a similar degree as the mitogens. However, the basal level of PKA activity is not sufficient to prevent mitogen-induced activation of MAPK. Therefore, proliferation of capillary endothelial cells is regulated by a balance between inhibitory and stimulatory signaling pathways.

\section{REFEREN CES}

Assender J W, Southgate KM, Hallett MB, N ewby AC (1992): Inhibition of proliferation, but not of $\mathrm{Ca}^{2}+$ mobilization, by cyclic AMP and GMP in rabbit aortic smooth-muscle cells. Biochem J 288:527-532.

Bacic F, McCarron RM, U ematsu S, Spatz M (1992): Adrenergic receptors coupled to adenylate cyclase in human cerebromicrovascular endothelium. Metab Brain Dis 7:125-137.

Barbara J G, Takeda K (1995): Voltage-dependent currents and modulation of calcium channel expression in zona fasciculata cells from rat adrenal gland. J Physiol 488: 609-622.

Benschop RJ , Nijkamp FP, Ballieux RE, Heijnen CJ (1994): The effects of beta-adrenoceptor stimulation on adhesion of human natural killer cells to cultured endothelium. Br J Pharmacol 113:1311-1316.

Brooker G, Harper J F, Terasaki WL, Moylan RD (1979): Radioimmunoassay of cyclic AMP and cyclic GMP. Adv Cyclic Nucleotide Res 10:1-33.

Burgering BM, Pronk GJ , van Weeren PC, Chardin P, Bos J L (1993): CAMP antagonizes p21ras-directed activation of extracellular signal-regulated kinase 2 and phosphorylation of mSos nucleotide exchange factor. EMBO J 12: 4211-4220.

Chabre O, Cornillon F, Bottari SP, Chambaz EM, Vilgrain I (1995): Hormonal regulation of mitogen-activated protein kinase activity in bovine adrenocortical cells: Crosstalk between phosphoinositides, adenosine 3', $5^{\prime}$-monophosphate, and tyrosine kinase receptor pathways. Endocrinology 136:956-964. 
Chijiwa T, Mishima A, Hagiwara M, Sano M, Hayashi K, I noue T, Naito K, Toshioka T, Hidaka H (1990): I nhibition of forskolin-induced neurite outgrowth and protein phosphorylation by a newly synthesized selective inhibitor of cyclic AMP-dependent protein kinase, N-[2-(p-bromocinnamylamino)ethyl]-5-isoquinolinesulfonamide $(\mathrm{H}-89)$, of PC12D pheochromocytoma cells. J Biol Chem 265:52675272.

Connolly DT, Olander J V, Heuvelman D, Nelson R, Monsell R, Siegel N, Haymore BL, Leimgruber R, Feder J (1989): Human vascular permeability factor. I solation from U 937 cells. J Biol Chem 264:20017-20024.

Cook SJ , McCormick F (1993): Inhibition by CAMP of Rasdependent activation of Raf. Science 262:1069-1072.

D'Angelo G, Struman I, Martial J , Weiner RI (1995): Activation of mitogen-activated protein kinases by vascular endothelial growth factor and basic fibroblast growth factor in capillary endothelial cells is inhibited by the antiangiogenic factor $16-\mathrm{kDa} \mathrm{N}$-terminal fragment of prolactin. Proc Natl Acad Sci U S A 92:6374-6378.

Dent P, Haser W, Haystead TA, Vincent LA, Roberts TM, Sturgill TW (1992): Activation of mitogen-activated protein kinase kinase by v-Raf in NIH 3 T3 cells and in vitro. Science 257:1404-1407.

de Vries C, Escobedo J A, Ueno H, Houck K, Ferrara N, Williams LT (1992): The fms-liketyrosinekinase, a receptor for vascular endothelial growth factor. Science 255 : 989-991.

Esch F, Baird A, Ling N, Ueno N, Hill F, Denoroy L, Klepper R, Gospodarowicz D, Bohlen P, Guillemin R (1985): Primary structure of bovine pituitary basic fibroblast growth factor (FGF) and comparison with the amino-terminal sequence of bovine brain acidic FGF. Proc Natl Acad Sci U S A 82:6507-6511.

Ferrara N, Henzel WJ (1989): Pituitary follicular cells secrete a novel heparin-binding growth factor specific for vascular endothelial cells. Biochem Biophys Res Commun 161:851-858.

Ferrara N, Clapp C, Weiner R (1991): The 16K fragment of prolactin specifically inhibits basal or fibroblast growth factor stimulated growth of capillary endothelial cells. Endocrinology 129:896-900.

Ferrara N, Houck K, J akeman L, Leung DW (1992): MolecuIar and biological properties of the vascular endothelial growth factor family of proteins. Endocr Rev 13:18-32.

Folkman J (1985): Tumor angiogenesis. Adv Cancer Res 43:175-203.

Folkman J, Shing Y (1992): Angiogenesis. J Biol Chem 267:10931-10934.

Fujii M, Ide T, Wadhwa R, Tahara H, Kaul SC, Mitsui Y, Ogata T, Oishi M, Ayusawa D (1995): I nhibitors of CGMPdependent protein kinase block senescence induced by inactivation of T antigen in SV40-transformed immortal human fibroblasts. Oncogene 11:627-634.

Galea P, Thibault G, Lacord M, Bardos P, Lebranchu Y (1993): IL-4, but not tumor necrosis factor-alpha, increases endothelial cell adhesiveness for lymphocytes by activating a CAMP-dependent pathway. J Immunol 151: 588-596.

Gospodarowicz D, Cheng J (1986): Heparin protects basic and acidicFGF from inactivation. J Cell Physiol 128:475484.

Graves LM, Bornfeldt KE, Raines EW, Potts BC, Macdonald SG, Ross R, Krebs EG (1993): Protein kinaseA antagonizes platel et-derived growth factor-induced signaling by mitogen-activated protein kinase in human arterial smooth muscle cells. Proc Natl Acad Sci U S A 90:1030010304.

Habener J F (1990): Cyclic AMP response element binding proteins: A cornucopia of transcription factors. Mol Endocrinol 4:1087-1094.

Hafner S, Adler HS, Mischak H, J anosch P, Heidecker G, Wolfman A, Pippig S, Lohse M, U effing M, Kolch W (1994): Mechanism of inhibition of Raf-1 by protein kinaseA. Mol Cell Biol 14:6696-6703.

Hordijk PL, Verlaan I, J alink K, van Corven EJ , Moolenaar WH (1994): CAMP abrogates the p21ras-mitogen-activated protein kinase pathway in fibroblasts. J Biol Chem 269:3534-3538.

Howe LR, Leevers SJ, Gomez N, Nakielny S, Cohen P, Marshall CJ (1992): Activation of the MAP kinase pathway by the protein kinase raf. Cell 71:335-342.

I da R, Lee A, Huang J , Brandi ML, Yamaguchi DT (1994): Prostaglandin-stimulated second messenger signaling in bone-derived endothelial cells is dependent on confluency in culture. J Cell Physiol 160:585-595.

Kaur G, Viallet J , Lorda J , Blair O, Gazdar AF, Minna J D, Sausville EA (1992): Growth inhibition by cholera toxin of human lung carcinoma cell lines: Correlation with GM 1 ganglioside expression. Cancer Res 52:3340-3346.

Klagsbrun M, D'Amore PA (1991): Regulators of angiogenesis. Annu Rev Physiol 53:217-239.

Kyriakis J M, App H, Zhang XF, Banerjee P, Brautigan DL, Rapp UR, Avruch J (1992): Raf-1 activates MAP kinasekinase. Nature 358:417-421.

Lange-Carter CA, Pleiman CM, Gardner AM, Blumer KJ , J ohnson GL (1993): A divergence in the MAP kinase regulatory network defined by MEK kinase and Raf. Science 260:315-319.

Lee PL, J ohnson DE, Cousens LS, Fried VA, Williams LT (1989): Purification and complementary DNA cloning of a receptor for basic fibroblast growth factor. Science 245: 57-60.

Leibovich SJ , Polverini PJ (1984): Protaminesulfateinhibition of serum-induced mitogenic responses: Differential effects on normal and neoplastic cells. J Natl Cancer Inst 73:1337-1347.

Leitman DC, Fiscus RR, Murad F (1986): Forskolin, phosphodiesterase inhibitors, and cyclic AMP analogs inhibit proliferation of cultured bovine aortic endothelial cells. J Cell Physiol 127:237-243.

Loesberg C, van Wijk R, Zandbergen J , van Aken WG, van Mourik J A, de Groot PG (1985): Cell cycle-dependent inhibition of human vascular smooth musclecell proliferation by prostaglandin E1. Exp Cell Res 160:117-125.

Macdonald SG, Crews CM, Wu L, Driller J , Clark R, Erikson RL, McCormick F (1993): Reconstitution of the Raf-1MEK-ERK signal transduction pathway in vitro. Mol Cell Biol 13:6615-6620 (published erratum appears in Mol Cell Biol (1994) 14:2223-2224).

Maione TE, Gray GS, Petro J , Hunt AJ , Donner AL, Bauer SI, Carson HF, Sharpe RJ (1990) Inhibition of angiogenesis by recombinant human platel et factor- 4 and related peptides. Science 247:77-79.

Manolopoulos VG, Samet MM, Lelkes PI (1995): Regulation of the adenylyl cyclase signaling system in various types of cultured endothelial cells. J Cell Biochem 57:590598. 
Nantel F, Bouvier M, Strosberg D, Marullo S (1995): Functional effects of long-term activation on human $\beta 2$ - and $\beta 1$-adrenocepror signalling. $\mathrm{Br} J$ Pharmacol 114:10451051.

Nilsson J, Olsson AG (1984): Prostaglandin E 1 inhibits DNA synthesis in arterial smooth muscle cells stimulated with platelet-derived growth factor. Atherosclerosis 53:77-82.

Nishizuka Y (1986): Studies and perspectives of protein kinase C. Science 233:305-312.

Pastan IH, J ohnson GS, Anderson WB (1975): Role of cyclic nucleotides in growth control. Annu Rev Biochem 44:491522.

Post SR, Aguila-Buhain O, Insel PA (1996): A key role for protein kinase $A$ in homologous desensitization of the beta 2-adrenergic receptor pathway in S49 Iymphoma cells. J Biol Chem 271:895-900.

Ross EM, Maguire ME, Sturgill TW, Biltonen RL, Gilman AG (1977): Relationship between the beta-adrenergic receptor and adenylate cyclase. J Biol Chem 252:57615775.

Salomon Y, Londos C, Rodbell M (1974): A highly sensitive adenylate cyclase assay. Anal Biochem 58:541-548.
Sevetson BR, Kong X, Lawrence J J r (1993): Increasing CAMP attenuates activation of mitogen-activated protein kinase. Proc Natl Acad Sci U S A 90:10305-10309.

Thomas KA (1987): Fibroblast growth factors. FASEB J 1:434-440.

Tool AT, Verhoeven AJ (1995): Inhibition of the production of platelet activating factor and of leukotriene B4 in activated neutrophils by nimesulide due to an elevation of intracellular cyclic adenosine monophosphate. Arzneimittelforschung 45:1110-1114.

Ullrich A, Schlessinger J (1990): Signal transduction by receptors with tyrosine kinase activity. Cell 61:203-212.

van Corven EJ , Hordijk PL, Medema RH, Bos J L, Moolenaar WH (1993): Pertussis toxin-sensitive activation of p21ras by $\mathrm{G}$ protein-coupled receptor agonists in fibroblasts. Proc Natl Acad Sci U S A 90:1257-1261.

Wu J , Dent P, J elinek T, Wolfman A, Weber MJ , Sturgill TW (1993): I nhibition of the EGF-activated MAP kinase signaling pathway by adenosine $3^{\prime}, 5^{\prime}$-monophosphate. Science 262:1065-1069.

Zhou Q, Hulea S, Kummerow FA (1995): Effects of adrenochrome and epinephrine on human arterial endothelial cells in vitro. Res Commun Mol Pathol Pharmacol 89:111126. 